\title{
Profitabilitas, Likuiditas, dan Rasio Aktivitas Pengaruhnya terhadap Nilai Perusahaan Pertambangan Sub Sektor Batubarayang Terdaftar di BEI periode 2016-2018
}

\author{
Novita Dwi Andriani ${ }^{1}$, Yofhi Septian Panglipurningrum ${ }^{2 *}$ \\ 1,2Program Studi Akuntansi, STIE AUB Surakarta \\ *Coresponding Author's email: yofhi.septian@stie-aub.ac.id
}

\begin{abstract}
Abstrak Tujuan dari penelitian ini untuk mengetahui pengaruh profitabilitas, likuiditas dan rasio aktivitas terhadap nilai perusahaan pada perusahaan pertambangan sub sektor batubara yang terdaftar di Bursa Efek Indonesia. Periode dalam penelitian ini adalah 3 tahun, yaitu tahun 2016-2018. Penelitian ini menggunakan pendekatan kuantitatif. Sampel yang digunakan sebanyak 10 perusahaan. Teknik analisis data yang digunakan adalah regresi linier berganda. Hasil penelitian ini menunjukkan secara parsial profitabilitas berpengaruh negatif dan signifikan terhadap nilai perusahaan dengan nilai signifikansi sebesar 0,020. Likuiditas secara parsial berpengaruh negatif dan tidak signifikan terhadap nilai perusahaan dengan nilai signifikansi sebesar 0,465. Rasio aktivitas secara parsial berpengaruh positif dan tidak signifikan terhadap nilai perusahaan dengan nilai signifikansi sebesar 0,197. Secara simultan profitabilitas, likuiditas dan rasio aktivitas berpengaruh positif dan signifikan terhadap nilai perusahaan dengan nilai F signifikan sisa sebesar 0,048. Kemampuan variabel profitabilitas, likuiditas dan rasio aktivitas dalam menjelaskan nilai perusahaan $17,2 \%$ sebagaimana besarnya adjusted $R$ square 0,172 sedangkan sisanya sebesar $82,8 \%$ dipengaruhi faktor lain yang tidak dimasukkan ke dalam model penelitian.
\end{abstract}

Kata kunci: Nilai Perusahaan, Profitabilitas, Likuiditas, dan Rasio Aktivitas.

\section{Pendahuluan}

Perkembangan bisnis dalam dunia usaha terjadi karena pengaruh dinamika ekonomi, sosial, budaya dan teknologi. Setiap perusahaan harus mampu konsisten dalam memelihara bahkan meningkatkan kinerja agar mampu bersaing dengan pasar global demi kelangsungan hidup perusahaan. Kebutuhan dana yang besar sangat diperlukan perusahaan untuk memperluas bisnisnya. Go Public menjadi salah satu cara dalam perbaikan struktur modal, dengan ini perusahaan memperdagangkan sahamnya ke masyarakat umum, sehingga setiap saat publik dapat mengetahui data pergerakan nilai perusahaan. Batubara merupakan salah satu sumber daya energi yang dibutuhkan baik di dalam negeri maupun di luar negeri. 


\section{BuanaAkuntansi}

Novita dan Yofhi

Vol. 5 No. 2

ISSN 2528-1119

E-ISSN 2580-5452

Indonesia merupakan salah satu produsen dan eksportir batubara terbesar di dunia. Sektor batubara memiliki jumlah yang relatif paling besar diantara perusahaan pertambangan lainnya yang telah listing di Bursa Efek Indonesia.

Perusahaan memiliki tujuan jangka pendek dan jangka panjang. Memaksimalkan kekayaan atau nilai perusahaan bagi para pemegang saham menjadi tujuan jangka panjang perusahaan, sehingga setiap perusahaan dituntut untuk meningkatkan nilai perusahaannya. Faktor ini sangat dipertimbangkan oleh para investor untuk menanamkan modalnya. Nilai perusahaan dapat dilihat dari kemampuan perusahaan membayar dividen. Besarnya dividen dapat mempengaruhi harga saham dan akan meningkatkan nilai perusahaan (Irayanti \& Tumbel, 2014).

Penelitian ini menggunakan 3 faktor yang mempengaruhi nilai perusahaan yaitu profitabilitas, likuiditas dan rasio aktivitas. Faktor pertama yang dapat mempengaruhi nilai perusahaan adalah profitabilitas. Analisa (2011) menyatakan, nilai perusahaan dapat pula dipengaruhi oleh besar kecilnya profitabilitas yang dihasilkan oleh perusahaan. Profitabilitas menunjukkan kemampuan perusahaan memperoleh laba atau ukuran efektifitas pengelolaan manajemen perusahaan (Wiagustini, 2010:76).

Profitabilitas dianggap mempunyai pengaruh terhadap nilai perusahaan. Hal ini dibuktikan dengan sebuah perusahaan yang mempunyai tingkat kenaikan profit atau laba mencerminkan bahwa perusahaan tersebut mempunyai kinerja manajemen yang baik, sehingga mempunyai sinyal yang positif dari para investor, yang ditandai dengan permintaan saham yang tinggi dan berdampak pula terhadap naiknya harga saham. Meningkatnya harga saham berarti meningkat pula nilai perusahaan di mata investor.

PT Baramulti Suksessarana Tbk mengalami penurunan tingkat profitabilitas di tahun 2018 bila dibandingkan tahun 2017. Margin usaha Perseroan turun menjadi $20,97 \%$ dari semula $28,46 \%$. Margin laba bersih yang sebelumnya mencapai $21,10 \%$, kini mencapai $15,57 \%$. Margin EBITDA yang sebelumnya mencapai $31,41 \%$, kini sebesar $24,48 \%$. Selain itu, imbal hasil atas aset serta imbal hasil atas ekuitas juga menurun masing-masing menjadi $28,18 \%$ dan $45,96 \%$ dari sebelumnya sebesar $39,41 \%$ dan $55,25 \%$. Penurunan profitabilitas tersebut dipengaruhi oleh penurunan harga jual, terutama di kuartal IV 2018, dan kenaikan harga kontraktor tahun 2018.

Faktor kedua yang dapat mempengaruhi nilai perusahaan adalah likuiditas. Likuiditas merupakan kemampuan perusahaan untuk membayar kewajiban jangka pendek perusahaan. Tingkat likuiditas yang tinggi menunjukkan bahwa perusahaan tidak mengalami kesulitan membayar kewajibannya dalam jangka pendek, sehingga kreditur tidak perlu khawatir dalam memberikan pinjaman (Amanah, 2014). Likuiditas mempunyai pengaruh terhadap nilai perusahaan. Perusahaan yang memiliki likuiditas yang baik maka akan dianggap memiliki kinerja yang baik oleh investor, sehingga dapat dikatakan perusahaan likuid dan mampu mengatasi utang jangka pendek serta dapat meningkatkan produktivitas perusahaan yang dapat menambah nilai perusahaan. Hal ini akan menarik minat investor untuk menanamkan modalnya pada perusahaan.

PT Adaro Energy Tbk membayar utang sebesar US\$258 juta pada tahun 2018 dan menjaga likuiditas tetap tinggi pada US $\$ 1.278$ juta, terdiri dari US\$928 juta dalam bentuk kas, US\$89 juta dalam bentuk aset keuangan yang tersedia untuk dijual dan US\$261 juta dalam bentuk fasilitas pinjaman yang belum dipakai. Posisi likuiditas ini memberikan fleksibilitas untuk dapat 


\section{BuanaAkuntansi}

Novita dan Yofhi

Vol. 5 No. 2

ISSN 2528-1119

E-ISSN 2580-5452

memenuhi pembayaran utang selanjutnya. Selain itu pada PT Bara Jaya Internasional, rasio lancar di tahun 2018 sebesar 25,23\% lebih baik dibandingkan dengan 2017 sebesar 19,57\%, meskipun rasio lancar di tahun 2018 lebih baik dibandingkan 2017 namun belum dapat menutupi kewajiban hutang lancanya. Rasio jumlah utang lancar terhadap jumlah aset di tahun 2018 mencapai 0,25 x dibandingkan 0,22 x di tahun 2017, dan 0,15 x di tahun 2016. Dengan meningkatnya perbandingan rasio kewajiban lancar terhadap jumlah Aset dari tahun 2016, 2017 dan 2018, Perseroan mengalami penurunan kemampuan dalam menyelesaikan seluruh utang jangka pendek dengan baik.

Faktor ketiga yang dapat mempengaruhi nilai perusahaan adalah rasio aktivitas. Rasio aktivitas menunjukkan keefisiensian perusahaan dalam menggunakan asetnya dan diproksikan dengan total aset turnover (TATO). TATO dapat mengukur efisiensi tingkat penggunaan seluruh aktiva dalam perusahaan (Fahmi, 2012: 135). Rasio aktivitas mempunyai pengaruh terhadap nilai perusahaan. Rasio aktivitas menggambarkan efektivitas penggunaan seluruh aktiva perusahaan dalam rangka menghasilkan penjualan atau berapa rupiah penjualan bersih yang dapat dihasilkan dari setiap rupiah yang diinvestasikan dalam bentuk harta perusahaan. Semakin tinggi rasio aktivitas maka semakin baik nilai perusahaan.

PT Baramulti Suksessarana Tbk pada tahun 2018 berhasil membukukan penjualan sebesar US $\$ 443,43$ juta, naik US $\$ 50,86$ juta atau 12,96\% dari tahun 2017 yang mencapai US $\$ 392,57$ juta. Hal tersebut dipengaruhi oleh peningkatan kuantitas penjualan tahun 2018 yang mencapai 10,59 juta ton dibandingkan tahun 2017 yang hanya sebesar 9,39 juta ton. Pada tahun 2018 di aset lancar mencapai US $\$ 90,46$ juta, lebih tinggi $14,69 \%$ atau US $\$ 11,59$ juta dari tahun sebelumnya yang tercatat sebesar US $\$ 78,87$ juta. Peningkatan aset lancar terutama didorong oleh peningkatan persediaan sebesar US $\$ 10,39$ juta. Aset tidak lancar pada tahun 2018 naik $17,81 \%$ atau US $\$ 23,38$ juta menjadi US\$154,64 juta bila dibandingkan tahun 2017 yang tercatat sebesar US\$131,26 juta. Kenaikan tersebut dipicu oleh kenaikan aset pertambangan yang meningkat US\$23,04 juta menjadi US\$62,30 juta dari sebelumnya sebesar US\$39,26 juta.

Hasil penelitian yang menguji 13 perusahaan manufaktur yang mewakili 19 sub-sektor perusahaan industri periode 2006-2008 atas pengaruh Ukuran Perusahaan, Leverage, Profitabilitas Dan Kebijakan Dividen terhadap Nilai Perusahaan menggunakan perhitungan PBV sementara Profitabilitas menggunakan pengukuran ROE. Temuan penelitian menyimpulkan bahwa secara parsial hanya Ukuran Perusahaan dan Profitabilitas, yang berpengaruh positif dan signifikan terhadap Nilai Perusahaan (Analisa, 2011). Hasil penelitian menguji 23 perusahaan manufaktur selama 2010-2014 atas pengaruh Profitabilitas, Rasio Aktivitas, Keputusan Pendanaan, Keputusan Investasi Terhadap Nilai Perusahaan menggunakan perhitungan PBV sementara Profitabilitas dan Rasio Aktivitas masing-masing menggunakan pengukuran ROA dan TATO. Temuan penelitian menyimpulkan bahwa secara parsial Profitabilitas, Rasio Aktivitas dan Keputusan Pendanaan berpengaruh secara signifikan terhadap Nilai Perusahaan (Rinnaya, Yansim Andini \& Oemar, 2016).

Hasil conference paper dengan tema The National Conferences Management and Business (NCMAB) 2018, yang menguji 12 perusahaan pertambangan di tahun 2012-2016 atas pengaruh CSR, Profitabilitas dan Likuiditas terhadap Nilai Perusahaan dengan proksi Tobins Q sementara profitabilitas dan likuiditas masing-masing menggunakan proksi ROA dan CR. Temuan penelitian menyimpulkan bahwa CSR dan Profitabilitas berpengaruh positif secara signifikan sementara Likuiditas tidak berpengaruh terhadap Nilai Perusahaan (Syamsudin \& 


\section{BuanaAkuntansi}

Novita dan Yofhi

Vol. 5 No. 2

ISSN 2528-1119

E-ISSN 2580-5452

Wardani, 2018). Hasil penelitian yang menguji 16 perusahaan manufaktur sub sektor logam periode 2014-2016 atas pengaruh Profitabilitas, Solvabilitas, Likuiditas, dan Inflasi terhadap Nilai Perusahaan menggunakan perhitungan PBV sementara Profitabilitas dan Likuiditas menggunakan pengukuran ROE dan CR. Temuan penelitian menyimpulkan bahwa Profitabilitas berpengaruh positif dan Likuditas berpengaruh negatif dan masing-masing secara signifikan terhadap Nilai Perusahaan (Permana \& Rahyuda, 2018). Hasil penelitian yang menguji 8 dari 10 perusahaan farmasi periode 2014-2017 atas pengaruh profitabilitas, struktur aktiva dan pertumbuhan penjualan terhadap struktur modal. Temuan penelitian menyimpulkan bahwa Profitabilitas berpengaruh negatif dan signifikan terhadap struktur modal (Panglipurningrum \& Dwiyani, 2019)

Reviu penelitian di atas memiliki persamaan dimana profitabilitas dengan pengukuran ROA dan ROE mampu membuktikan pengaruh positif terhadap Nilai perusahaan sementara Likuiditas tidak berpengaruh dan memiliki arah pengaruh negatif terhadap nilai perusahaan sementara rasio aktivitas juga memiliki pengaruh positif dan signifikan. Gap penelitian ini dapat dipahami bahwa ketika menggunakan proksi PBV untuk mengukur nilai perusahaan menghasilkan nilai likuiditas yang berlawanan dengan hasil penelitian terdahulu sehingga penting untuk dilakukan pengujian lebih lanjut dimana ketiga rasio keuangan ini merupakan rasio yang penting untuk mengukur nilai perusahaan. Perbedaan penelitian ini adalah memperbaharui periode pengamatan yaitu 2016-2018 Berdasarkan latar belakang dan fenomena yang dikemukakan di atas, penelitian ini bertujuan untuk mengetahui lebih lanjut mengenai pengaruh profitabilitas, likuiditas dan rasio aktivitas terhadap nilai perusahaan. Subjek penelitian ini dilakukan pada perusahaan pertambangan sub sektor batubara di Bursa Efek Indonesia.

\section{Tinjauan Pustaka}

\subsection{Nilai Perusahaan}

Menurut Kismono (2010) nilai perusahaan merupakan suatu hal yang penting karena dengan nilai perusahaan yang tinggi akan diikuti oleh tingginya kemakmuran pemegang saham. Semakin tinggi harga saham maka semakin tinggi pula nilai suatu perusahaan. Kekayaan pemegang saham dan perusahaan dipresentasikan oleh harga pasar dan saham yang merupakan cerminan dari keputusan investasi, pendanaan, dan manajemen aset.

Menurut Agus Sartono (2014: 487) rasio-rasio pengukuran nilai perusahaan diantaranya:

1. Price Earning Ratio (PER)

Price Earning Ratio (PER) menunjukkan berapa banyak jumlah uang yang rela dikeluarkan oleh investor untuk membayar setiap dolar laba yang dilaporkan. Rasio ini digunakan untuk mengukur seberapa besar perbandingan antara harga saham perusahaan dengan keuntungan yang diperoleh oleh para pemegang saham.

2. Price to Book Value (PBV)

Price to Book Value (PBV) menjelaskan seberapa besar pasar menghargai nilai buku saham suatu perusahaan. Makin tinggi rasio ini, menunjukkan pasar semakin percaya akan prospek perusahaan tersebut. PBV menunjukkan tingkat kemampuan perusahaan dalam menciptakan nilai perusahaan yang relatif terhadap jumlah modal yang 


\section{BuanaAkuntansi}

diinvestasikan. Perusahaan yang berjalan dengan baik, dapat diukur dengan rasio yang mencapai diatas satu, menunjukkan nilai pasar saham lebih besar dari nilai bukunya. Semakin besar rasio PBV maka semakin tinggi perusahaan dinilai oleh para pemodal relatif dibandingkan dengan dana yang telah ditanamkan diperusahaan.

3. Tobin's Q

Alternatif ini yang digunakan dalam mengukur nilai perusahaan adalah dengan menggunakan metode Tobin's $Q$ yang dihitung dengan membandingkan rasio nilai pasar saham perusahaan dengan nilai buku ekuitas perusahaan.

\subsection{Profitabilitas}

Menurut Munawir (2014: 33) profitabilitas yaitu menunjukkan kemampuan perusahaan untuk menghasilkan laba selama periode tertentu. Adapun menurut Kasmir (2014: 115) rasio profitabilitas adalah rasio untuk menilai kemampuan perusahaan dalam mencari keuntungan. Rasio ini juga memberikan ukuran tingkat efektivitas manajemen suatu perusahaan. Hal ini ditunjukkan oleh laba yang dihasilkan dari penjualan dan pendapatan investasi. Intinya dalam penggunaan rasio ini, menunjukkan efisiensi perusahaan.Menurut I Made Sudana (2011: 22) berikut adalah cara untuk mengukur rasio profitabilitas perusahaan:

1. Return On Assets (ROA)

ROA menunjukkan kemampuan perusahaan dengan menggunakan seluruh aktiva yang dimiliki untuk menghasilkan laba setelah pajak. Semakin besar ROA, semakin efisien penggunaan aktiva perusahaan atau dengan kata lain dengan jumlah aktiva yang sama bisa dihasilkan laba yang lebih besar, dan sebaliknya.

2. Return On Equity (ROE)

ROE menunjukkan kemampuan perusahaan untuk menghasilkan laba setelah pajak dengan menggunakan modal sendiri yang dimiliki perusahaan. Semakin tinggi rasio ini berarti semakin efisien penggunaan modal sendiri yang dilakukan oleh pihak manajemen perusahaan.

3. Profit Margin Ratio

Profit margin rasio mengukur kemampuan perusahaan untuk menghasilkan laba dengan menggunakan penjualan yang dicapai perusahaan. Semakin tinggi rasio menunjukkan bahwa perusahaan semakin efisien dalam menjalankan operasinya. Profit margin rasio dibedakan menjadi:

a) Net Profit Margin

Rasio ini mengukur kemampuan perusahaan dalam menghasilkan laba bersih dari penjualan perusahaan.

b) Operating Profit Margin

Rasio ini mengukur kemampuan menghasilkan laba sebelum pajak dan bunga dengan penjualan yang dilakukan perusahaan.

c) Gross Profit Margin

Rasio ini mengukur kemampuan perusahaan untuk menghasilkan laba kotor dengan penjualan di perusahaan.

d) Basic Earning Power 


\section{BuanaAkuntansi}

Rasio ini mengukur kemampuan perusahaan menghasilkan keuntungan sebelum bunga dan pajak dengan menggunakan keseluruhan aktiva yang dimiliki perusahaan.

\subsection{Likuiditas}

Likuiditas merupakan suatu indikator untuk mengukur kemampuan likuiditas jangka pendek perusahaan dengan melihat aktiva lancar perusahaan relatif terhadap utang lancarnya (Mamduh dan Abdul Halim, 2009: 75). Tingkat likuditas yang tinggi menunjukkan bahwa perusahaan tidak mengalami kesulitan membayar kewajibannya dalam jangka pendek, sehingga kreditur tidak perlu khawatir dalam memberikan pinjaman (Amanah, 2014). Rasio likuiditas terdiri dari:

1. Rasio Lancar (Current Ratio)

Rasio lancar (Current Ratio) menggambarkan kemampuan perusahaan memenuhi utang jangka pendeknya dengan menggunakan aktiva lancarnya (aktiva yang akan berubah menjadi kas dalam waktu satu tahun atau satu siklus bisnis). Rasio yang rendah menunjukkan risiko likuiditas yang tinggi, sedangkan rasio lancar yang tinggi menunjukkan adanya kelebihan aktiva lancar, yang akan mempunyai pengaruh yang tidak baik terhadap likuiditas perusahaan (Mamduh dan Abdul Halim, 2009: 75).

2. Quick Ratio (Acid Test Ratio)

Quick Ratio (Acid Test Ratio) merupakan ukuran uji solvensi jangka pendek yang lebih teliti daripada rasio lancar karena pembilangnya mengeliminasi persediaan yang dianggap aktiva lancar yang sedikit tidak likuid dan kemungkinan menjadi sumber kerugian (Fahmi, 2011: 125).

\subsection{Rasio Aktivitas}

Rasio aktivitas menjelaskan aktivitas perusahaan dalam menjalankan operasinya baik dalam kegiatan penjualan, dan kegiatan lainnya. Semua rasio aktivitas ini melibatkan perbandingan antara tingkat penjualan dan investasi pada berbagai jenis aktiva. Aktivitas perusahaan dalam penelitian ini diukur menggunakan rasio perputaran total aktiva. Rasio ini menghitung efektivitas penggunaan total aktiva. "Rasio ini menunjukkan kemampuan perusahaan dalam mengelola seluruh aset/investasi untuk menghasilkan penjualan" (Sugiono, 2009:77).

Rasio perputaran total aktiva merupakan ukuran efektivitas pemanfaatan aset dalam menghasilkan penjualan. Semakin tinggi perputarannya semakin efektif perusahaan memanfaatkan aktivanya. Memanfaatkan efektivitas aktiva dengan baik untuk menghasilkan penjualan akan memberikan dampak yang baik pula terhadap pendapatan dan laba.

\subsection{Kerangka Berpikir dan Hipotesis Penelitian}

Menurut Uma Sekaran, kerangka berfikir merupakan model konseptual tentang bagaimana teori berhubungan dengan berbagai faktor yang telah didefinisikan sebagai masalah yang penting (Sugiyono, 2016, hal. 91). Model itu sendiri dapat didefinisikan sebagai konstruksi melalui parameter spesifik yang diukur baik dalam struktur, bentuk, isi, jumlah dan makna 


\section{BuanaAkuntansi}

dengan batasan tertentu (Husain, 2019). Lebih lanjut, model penelitian menunjukkan hubungan antar variabel yang saling mempengaruhi dalam suatu penelitian (Supranto \& Limakrisna, 2019, hal. 31). Model penelitian ini disajikan pada Gambar 1.

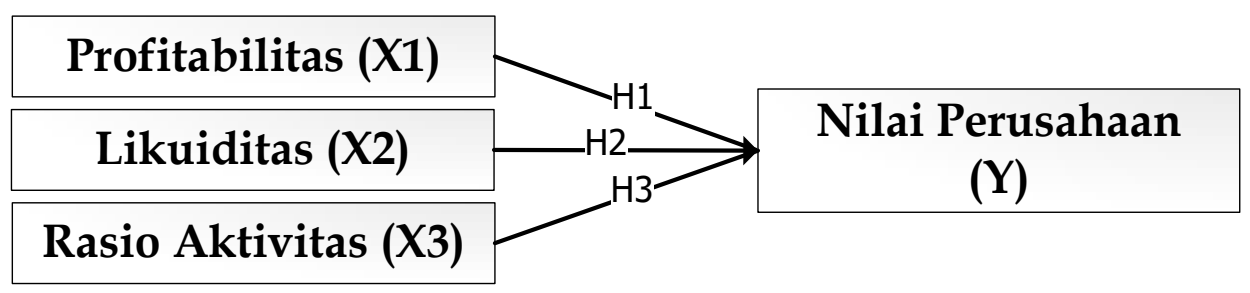

\section{Gambar 1.Model Penelitian}

Model penelitian di atas dinyatakan ke dalam pengembangan hipotesis berikut ini:

Profitabilitas merupakan rasio yang digunakan sebagai tolak ukur suatu perusahaan dalam memperoleh laba dengan persentase pada tingkat yang dapat diterima (Husain, Sarwani, Sunardi, \& Lisdawati, 2020). Rasio profitabilitas dapat diukur dengan dua pendekatan, yaitu pendekatan penjualan dan pendekatan investasi. Rasio ini juga dapat dianalisis untuk melihat sejauh mana suatu perusahaan memiliki kinerja keuangan baik dan benar dengan menggunakan aturan-aturan tersebut (Yanti, Isyanto, \& Mohd Saudi, 2020). Hasil penelitian yang menguji profitabilitas yang menghasilkan temuan pengaruh positif dan signifikan terhadap nilai perusahaan (Analisa, 2011; Rinnaya, Yansim Andini \& Oemar, 2016; Syamsudin \& Wardani, 2018; Permana \& Rahyuda, 2018). Profitabilitas yang tinggi menyebabkan perusahaan memiliki kepercayaan yang tinggi kepada investor untuk mengembalikan hasil investasinya yang pada akhirnya berdampak pada Nilai Perusahaan.

$\mathrm{H}_{1}$ : Profitabilitas berpengaruh positif terhadap Nilai Perusahaan

Likuiditas mencerminkan tingkat kemampuan perusahaan dalam konteks perusahaan menyatakan bahwa tidak mengalami kesulitan membayar kewajibannya dalam jangka pendek. Hasil penelitian yang menguji likuiditas perusahaan yang menghasilkan temuan pengaruh negatif dan signifikan terhadap nilai perusahaan dengan pengukuran PBV (Permana \& Rahyuda, 2018), sementara tidak signifikanya profitabilitas terhadap nilai perusahaan dengan proksi Tobin's Q (Syamsudin \& Wardani, 2018). Likuiditas perusahaan yang lancar menyebabkan perusahaan memiliki kelebihan aset yang akan mempunyai pengaruh yang baik terhadap investasi perusahaan dan struktur modal yang berdampak pada meningkatnya nilai perusahaan.

$\mathrm{H}_{2}$ : Likuiditas berpengaruh positif terhadap Nilai Perusahaan

Rasio aktivitas menggambarkan kinerja operasi perusahaan dalam aktivitas utama yaitu penjualan, aktivitas lainnya serta perputarannya. Hasil penelitian yang menguji Rasio Aktivitas yang menghasilkan temuan pengaruh psoitif dan signifikan terhadap nilai perusahaan dengan pengukuran PBV (Rinnaya, Yansim Andini \& Oemar, 2016). Rasio perputaran total aset yang tinggi menyebabkan perusahaan memiliki ketersediaan bahan baku yang cukup untuk menghasilkan penjualan yang pada akhirnya berdampak pada meningkatnya nilai perusahaan.

$\mathrm{H}_{3}$ : Rasio Aktivitas berpengaruh positif terhadap Nilai Perusahaan. 


\section{BuanaAkuntansi}

Novita dan Yofhi

Vol. 5 No. 2

ISSN 2528-1119

E-ISSN 2580-5452

\section{Metodologi Penelitian}

Penelitian ini menggunakan data sekunder, yaitu data yang diperoleh atau dikumpulkan oleh pihak lain yang melakukan penelitian dari sumber-sumber yang telah ada. Data sekunder ini berdasarkan data laporan keuangan dan laporan tahunan perusahaan pertambangan sub sektor batubara periode 2016-2018.

Metode pengumpulan data yang digunakan adalah metode dokumentasi yaitu mengumpulkan data atau dokumen dari laporan keuangan perusahaan pertambangan sub sektor batubara di Bursa Efek Indonesia (BEI), website, serta buku rujukan atau mengutip catatan yang relevan dengan masalah yang diteliti berupa Pengaruh Profitabilitas, Likuiditas dan Rasio Aktivitas terhadap Nilai Perusahaan dengan laporan keuangan yang telah diaudit dari tahun 2016-2018.

Pengukuran variabel penelitian ini terdiri dari 3 (tiga) variabel bebas dan 1 (satu) variabel independen, yaitu (1) Profitabilitas menggunakan proksi Return On Asset (ROA) yang mengukur kemampuan perusahaan dengan keseluruhan dana yang diinvestasikan dalam aset yang bertujuan menghasilkan keuntungan (Pratiwi \& Damayanthi, 2017) (2) Likuiditas menggunakan proksi current ratio (CR) yang mengukur kemampuan perusahaan untuk membayar utang jangka pendek tepat berdasarkan aset lancar yang diubah menjadi kas (Hanafi \& Halim, 2016, hal. 74); dan (3) Rasio Aktivitas menggunakan proksi total assets turnover (TATO) yang mengukur kemampuan perusahaan dalam mengelola seluruh aset atau investasi untuk menghasilkan penjualan (Sugiono, 2009, hal. 77). Nilai perusahaan yang dioperasikan menjadi variabel dependen menggunakan proksi price-to book value (PBV) yang menggambarkan perbandingan antara harga pasr saham per lembar dengan nilai bukunya.

Populasi dalam penelitian ini sebanyak 22 perusahaan. Pengambilan sampel yang digunakan adalah teknik random sampling atau sampel acak yang berjumlah 10 perusahaan pertambangan sub sektor batubara.

Metode analisis data adalah proses mencari dan menyusun secara sistematis data yang diperoleh dari hasil wawancara, catatan lapangan, dokumentasi, dan bahan-bahan lain, sehingga dapat mudah dipahami dan temuannya dapat di informasikan kepada orang lain (Sugiyono, 2016, hal. 244). Metode analisis data pada penelitian ini menggunakan analisis regresi linier berganda.

\section{Analisis dan Pembahasan}

Hasil pengujian tergantung pada metode analisis data dan menjelaskan tentang metode statistika yang digunakan dalam pengujian data, pengujian asumsi regresi, pengujian hipotesis beserta batasan-batasannya untuk dasar pengambilan keputusan menerima hipotesis atau tidak menerima hipotesis penelitian, berikut analisis hasil pengujian data:

\subsection{Statistik Deskriptif}

Tabel 1. Hasil Uji Statistik Deskriptif

\begin{tabular}{|l|c|c|c|c|c|}
\hline & \multicolumn{1}{c}{ N } & Min. & \multicolumn{1}{c}{ Max. } & Mean & Std. Deviation \\
\hline ROA & 30 & $-30,76$ & 39,41 & 8,8036 & 14,7416
\end{tabular}




\section{BuanaAkuntansi}

\begin{tabular}{l|c|c|c|c|c} 
CR & 30 & 17,72 & 405,09 & 173,0673 & 127,5262 \\
\hline TATO & 30 & 0,01 & 1,94 & 0,5870 & 0,6647 \\
\hline PBV & 30 & 0,60 & 5,44 & 2,2363 & 1,2286 \\
\hline Valid N (listwise) & 30 & & & &
\end{tabular}

Sumber: Output SPSS (2020)

Tabel 1 menjabarkan deskripsi variabel secara statistik yang terdapat di penelitian ini. Hasil deskriptif dari ke empat variabel dengan jumlah sampel sebanyak 10 adalah sebagai berikut: (1) Profitabilitas (ROA) mempunyai nilai minimum sebesar (-30,76); nilai maksimum adalah 39,41; nilai mean adalah 8,8036 dan standar deviasi adalah 14,7416. (2) Likuiditas (CR) mempunyai nilai minimum sebesar 17,72; nilai maksimum adalah 405,09; nilai mean adalah 173,0673 dan standar deviasi adalah 127,5262. (3) Rasio Aktivitas (TATO) mempunyai nilai minimum sebesar 0,01; nilai maksimum adalah 1,94; nilai mean adalah 0,5870 dan standar deviasi adalah 0,6647. (4) Nilai Perusahaan (PBV) mempunyai nilai minimum sebesar 0,60; nilai maksimum adalah 5,44; nilai mean adalah 2,2363 dan standar deviasi adalah 1,2286.

\subsection{Uji Asumsi Klasik}

\begin{tabular}{l} 
Tabel 2. Hasil Uji Normalitas \\
\begin{tabular}{|c|c|} 
Test of K-S & Asymp Sig. \\
\hline 0,088 & $0,200 \mathrm{c}, \mathrm{d}$ \\
\hline
\end{tabular} \\
\hline
\end{tabular}

Uji normalitas data menggunakan one sample Kolmogorov-smirnov test dengan ketentuan nilai kenormalan. Tabel 2 menunjukkan bahwa nilai signifikansi 0,200 lebih besar dari 0,05 sehinga dapat disimpulkan bahwa data yang diuji berdistribusi normal.

Tabel 3. Hasil Uji Heteroskedastisitas

\begin{tabular}{|c|c|c|}
\hline Model & T & Sig \\
\hline ROA & $-0,103$ & 0,919 \\
\hline CR & $-0,673$ & 0,507 \\
\hline TATO & 1,088 & 0,287 \\
\hline
\end{tabular}

Sumber: Output SPSS (2020)

Tabel 3 diketahui bahwa nilai signifikansi dari empat variabel independen lebih besar dari 0,05 maka dapat disimpulkan bahwa tidak terjadi gejala heteroskedastisitas pada model regresi.

Tabel 4. Hasil Uji Multikolinearitas

\begin{tabular}{|c|c|}
\hline \multicolumn{2}{|c|}{ Collinearity Statistic } \\
Tolerance & VIF \\
\hline 0,979 & 1,021 \\
\hline 0,975 & 1,026 \\
\hline 0,978 & 1,022 \\
\hline
\end{tabular}

Sumber: Output SPSS (2020) 


\section{BuanaAkuntansi}

Tabel 4 dapat diketahui bahwa semua variabel independen memiliki nilai tolerance> 0,10 dan nilai VIF<10. Hal ini dapat disimpulkan bahwa variabel Profitabilitas (ROA), Likuiditas (CR), Rasio Aktivitas (TATO) dan Nilai Perusahaan (PBV) dalam penelitian ini telah terbebas dari multikolinearitas sehingga tidak terjadi korelasi antar variabel independen.

Tabel 5. Hasil Uji Autokorelasi

\begin{tabular}{|c|c|}
\hline $\begin{array}{c}\text { Std. Error of } \\
\text { the Estimate }\end{array}$ & $\begin{array}{c}\text { Durbin- } \\
\text { Watson }\end{array}$ \\
\hline 1,11793 & 1,570 \\
\hline Sumber: Output SPSS (2020)
\end{tabular}

Dari tabel 5di atas dapat diketahui bahwa nilai Durbin-Watson (DW) yang diperoleh sebesar 1,570. Angka tersebut merupakan angka DW yang berada di antara (-2) sampai (+2). Berdasarkan kriteria tersebut, maka dapat disimpulkan bahwa dalam penelitian ini tidak ada autokorelasi antar variabel.

\subsection{Analisis Regresi Linier Berganda}

Tabel 6. Hasil Uji Autokorelasi

\begin{tabular}{|c|c|c|c|}
\hline Model & Beta & $\mathbf{t}$ & Sig. \\
\hline (constant) & & 5,212 & 0,000 \\
\hline ROA & $-0,423$ & $-2,478$ & 0,020 \\
\hline $\mathrm{CR}$ & $-0,127$ & $-0,742$ & 0,465 \\
\hline TATO & 0,226 & 1,324 & 0,197 \\
\hline
\end{tabular}

Persamaan regresinya yaitu, $Y=-0,423 \mathrm{X}_{1}-0,127 \mathrm{X}_{2}+0,226 \mathrm{X}_{3}$

Berdasarkan persamaan regresi linier berganda diatas diketahui bahwa:

1. Koefisien Profitabilitas (ROA) sebesar $(-0,423)$ artinya profitabilitas berpengaruh negatif terhadap nilai perusahaan. Apabila profitabilitas ditingkatkan sebesar satu satuan maka nilai perusahaan akan menurun sebesar 0,423 dengan asumsi likuiditas dan rasio aktivitas tetap atau konstan.

2. Koefisien Likuiditas (CR) sebesar $(-0,127)$ artinya likuiditas berpengaruh negatif terhadap nilai perusahaan. Apabila likuiditas ditingkatkan sebesar satu satuan maka nilai perusahaan akan menurun sebesar 0,127 dengan asumsi profitabilitas dan rasio aktivitas tetap atau konstan.

3. Koefisien Rasio Aktivitas (TATO) sebesar 0,226 artinya rasio aktivitas berpengaruh positif terhadap nilai perusahaan. Apabila rasio aktivitas ditingkatkan sebesar satu satuan maka nilai perusahaan akan meningkat sebesar 0,226 dengan asumsi profitabilitas dan likuiditas tetap atau konstan. 


\section{BuanaAkuntansi}

\subsection{Uji Hipotesis}

\section{Tabel 7. Hasil Uji-t}

\begin{tabular}{|c|c|c|}
\hline \multicolumn{1}{|c|}{ Model } & $\mathbf{t}$ & Sig. \\
\hline (constant) & 5,212 & 0,000 \\
\hline ROA & $-2,478$ & 0,020 \\
\hline CR & $-0,742$ & 0,465 \\
\hline TATO & 1,324 & 0,197 \\
\hline
\end{tabular}

Sumber: Output SPSS (2020)

Berdasarkan hasil pengujian tabel 7 dapat dilihat bahwa:

1. Nilai signifikansi Profitabilitas (ROA) sebesar 0,020<0,05 sehingga profitabilitas berpengaruh signifikan terhadap nilai perusahaan. Kesimpulan dari pengujian ini adalah hipotesis 1 terbukti.

2. Nilai signifikansi Likuiditas (CR) sebesar 0,465 > 0,05 sehingga likuiditas berpengaruh tidak signifikan terhadap nilai perusahaan. Kesimpulan dari pengujian ini adalah hipotesis 2 tidak terbukti.

3. Nilai signifikansi Rasio Aktivitas (TATO) sebesar 0,197 >0,05 sehingga rasio aktivitas berpengaruh tidak signifikan terhadap nilai perusahaan. Kesimpulan dari pengujian ini adalah hipotesis 3 tidak terbukti.

\section{Tabel 8. Hasil Uji-F}

\begin{tabular}{|c|c|}
\hline F & Sig \\
\hline 3,009 & $0,048^{\mathrm{b}}$ \\
\hline
\end{tabular}

Sumber: Output SPSS (2019)

Berdasarkan tabel 8, menunjukkan nilai signifikansi Profitabilitas, Likuiditas dan Rasio Aktivitas sebesar 0,048 $<0,05$ sehingga Profitabilitas, Likuiditas, dan Rasio Aktivitas secara simultan berpengaruh signifikan terhadap Nilai Perusahaan pada perusahaan Pertambangan sub sektor batubara yang terdaftar di BEI pada tahun 2016-2018.

\begin{tabular}{|c|c|}
\hline Tabel 9. Hasil Koefisien Determinasi $\left(\mathbf{R}^{2}\right)$ \\
\hline Adjusted R Square & Std. Error Of the Estimate \\
\hline 0,172 & 1,11793 \\
\hline
\end{tabular}

Sumber: Output SPSS (2019)

Berdasarkan tabel 9, didapatkan hasil sebesar 0,172 yang berarti keragaman Nilai Perusahaan mampu dijelaskan oleh variabel Profitabilitas, Likuiditas dan Rasio Aktivitas sebesar 17,2\% sedangkan sisanya $82,8 \%$ dijelaskan oleh variabel lain yang tidak ikut di observasi, antara lain Solvabilitas, Struktur Modal, Ukuran Perusahaan dan lainnya.

\subsection{Pembahasan}




\section{BuanaAkuntansi}

Novita dan Yofhi

Vol. 5 No. 2

ISSN 2528-1119

E-ISSN 2580-5452

Interprestasi mengenai pengaruh profitabilitas, likuiditas dan rasio aktivitas terhadap nilai perusahaan Pertambangan sub sektor batubara yang terdaftar di BEI periode 2016-2018 adalah sebagai berikut:

\subsubsection{Pengaruh Profitabilitas terhadap Nilai Perusahaan}

Hasil perhitungan analisis regresi untuk variabel profitabilitas diperoleh nilai koefisien regresi sebesar $(-0,423)$ dan nilai signifikansi sebesar $0,020<0,05$. Dapat disimpulkan bahwa profitabilitas berpengaruh negatif dan signifikan terhadap nilai perusahaan. Hal ini berarti dengan meningkatnya profitabilitas justru menyebabkan nilai perusahaan akan menurun. Begitu juga sebaliknya menurunnya profitabilitas akan menaikkan nilai perusahaan. Tinggi rendahnya ROA tergantung pada pengelolaan aset perusahaan oleh manajemen yang menggambarkan efisiensi dari operasional perusahaan. Profitabilitas yang negatif dan signifikan menunjukkan manajemen perusahaan tidak berhasil meningkatkan nilai perusahaan bagi pemilik perusahaan sesuai dengan tujuan manajemen keuangan yaitu memaksimumkan nilai perusahaan. Untuk itu perusahaan harus mengoreksi kembali prospek kegiatan yang dijalankan perusahaan agar lebih produktif sehingga para pemegang saham akan merasakan keuntungan yang lebih besar dari biaya modalnya.

Temuan ini mendukung penelitian terdahulu yang relevan berhubungan dengan pengaruh profitabilitas terhadap nilai perusahaan yang dilakukan oleh Syamsudin, Betik Kusuma Wardani (2018), Dwi Astutik (2017), Ista Yansi Rinnaya, Rita Andini, Abrar Oemar (2016), A.A.Ngr Bgs Aditya Permana, Henry Rahyuda (2018), menyatakan dalam hasil penelitiannya bahwa Profitabilitas berpengaruh signifikan terhadap Nilai Perusahaan. Temuan yang berbeda dengan hasil penelitian pengaruh Profitabilitas terhadap Nilai Perusahaan yang dilakukan oleh

Langkah yang perlu dilakukan perusahaan terhadap profitabilitas yaitu mengoptimalkan kinerja dengan cara melakukan efisiensi pada beban-beban operasional perusahaan, mengoptimalkan laba bersih, serta mengurangi jumlah aktiva tetap yang tidak produktif.

\subsubsection{Pengaruh Likuiditas terhadap Nilai Perusahaan}

Hasil perhitungan analisis regresi untuk variabel likuiditas diperoleh nilai koefisien regresi sebesar $(-0,127)$ dan nilai signifikansi sebesar $0,465>0,05$. Dapat disimpulkan bahwa likuiditas berpengaruh negatif dan tidak signifikan terhadap nilai perusahaan. Likuiditas yang tinggi apabila dilihat dari perspektif kreditur perusahaan dalam kondisi ini akan dinilai baik. Disisi lain apabila dilihat dari perspektif investor dan calon investor justru dinilai perusahaan tidak mempunyai kemampuan memutar modal kerjanya. Akibatnya banyak dana yang menganggur, sehingga kemampuan perusahaan dalam memperoleh profit juga rendah. Hal ini perlu dijadikan perhatian bagi manajemen perusahaan, karena mampu memenuhi kewajiban jangka pendek tidak menjamin nilai perusahaan akan naik. Artinya pembentukan likuiditas yang berlebihan (overlikuid) kondisi tidak bagus, karena akan berakibat dana untuk investasi dalam menghasilkan profit berkurang. Dalam penelitian ini dapat dikatakan bahwa seorang investor dalam melakukan investasi tidak selalu memperhatikan faktor likuiditas yang dimiliki oleh perusahaan. Karena rasio ini hanya menunjukkan kemampuan perusahaan untuk menutupi utang lancar dengan aktiva lancar saja, hal ini berarti posisi likuiditas tidak selalu diperhitungkan investor dalam berinvestasi. 


\section{BuanaAkuntansi}

Novita dan Yofhi

Vol. 5 No. 2

ISSN 2528-1119

E-ISSN 2580-5452

Hasil penelitian ini mendukung temuan Syamsudin, Betik Kusuma Wardani (2018), menyatakan dalam hasil penelitiannya bahwa Likuiditas berpengaruh tidak signifikan terhadap Nilai Perusahaan, sedangkan hasil penelitian yang dilakukan oleh A.A.Ngr Bgs Aditya Permana, Henry Rahyuda (2019), menyatakan bahwa Likuiditas berpengaruh signifikan terhadap Nilai Perusahaan.

Langkah yang perlu dilakukan oleh perusahaan adalah mengoptimalkan kualitas rasio likuiditas dan mempertahankan rasio likuiditas yang dimiliki perusahaan, dengan melihat aset lancar dan kewajiban lancar. Aset lancar seperti kas, piutang usaha serta kewajiban lancar seperti hutang jangka pendek yang berupa laba ditahan.

\subsubsection{Pengaruh Rasio Aktivitas Terhadap Nilai Perusahaan}

Hasil perhitungan analisis regresi untuk variabel profitabilitas diperoleh nilai koefisien regresi sebesar 0,226 dan nilai signifikansi sebesar 0,197 >0,05. Dapat disimpulkan bahwa rasio aktivitas berpengaruh positif dan tidak signifikan terhadap nilai perusahaan. Hasil penelitian menunjukkan bahwa rasio aktivitas berpengaruh positif dan tidak signifikan terhadap nilai perusahaan. Hal ini disebabkan data penjualan perusahaan yang dijadikan sampel mengalami ketidakstabilan kenaikan atau pertumbuhan. Perusahaan menunjukkan perbandingan yang kecil antara penjualan dengan total aktiva, dimana terdapat beberapa perusahaan yang memiliki aktiva tinggi tetapi tingkat penjualan yang dihasilkan rendah. Aktivitas perusahaan yang efektif ternyata belum tentu menaikkan laba atau pendapatan perusahaan, sehingga kurang menjadi pertimbangan investor dalam keputusan investasi.

Hasil penelitian ini mendukung temuan Dwi Astutik (2017), menyatakan dalam hasil penelitiannya bahwa Rasio Aktivitas berpengaruh tidak signifikan terhadap Nilai Perusahaan, sedangkan temuan ini tidak mendukung temuan Ista Yansi Rinnaya, Abrar Oemar (2016) menyatakan bahwa Rasio Aktivitas berpengaruh signifikan terhadap Nilai Perusahaan.

Langkah yang perlu dilakukan oleh perusahaan adalah mengoptimalkan perputaran aktiva yang dapat menunjang kegiatan penjualan menjadi stabil. Meningkatnya penjualan dapat menaikkan pendapatan perusahaan yang berpengaruh terhadap harga saham sehingga nilai perusahaan meningkat.

\section{Kesimpulan, Keterbatasan, dan Saran}

Berdasarkan hasil penelitian yang telah dilakukan setelah melalui tahap pengumpulan data, pengolahan data, dan penginterprestasikan hasil analisis Profitabilitas, Likuiditas, dan Solvabilitas terhadap Nilai Perusahaan, maka hasil penelitian ini dapat disimpulkan bahwa:

1. Variabel Profitabilitas berpengaruh negatif dan signifikan terhadap Nilai Perusahaan pada perusahaan Pertambangan sub sektor batubara yang terdaftar di Bursa Efek Indonesia periode 2016-2018.

2. Variabel Likuiditas berpengaruh negatif dan tidak signifikan terhadap Nilai Perusahaan pada perusahaan Pertambangan sub sektor batubara yang terdaftar di Bursa Efek Indonesia periode 2016-2018.

3. Variabel Rasio Aktivitas berpengaruh positif dan tidak signifikan terhadap Nilai Perusahaan pada perusahaan Pertambangan sub sektor batubara yang terdaftar di Bursa Efek Indonesia periode 2016-2018. 


\section{BuanaAkuntansi}

4. Hasil uji F menyatakan bahwa Profitabilitas, Likuiditas, dan Rasio Aktivitas secara simultan atau bersama-sama berpengaruh signifikan terhadap Nilai Perusahaan pada perusahaan Pertambangan sub sektor batubara yang terdaftar di Bursa Efek Indonesia periode 2016-2018.

5. Nilai koefisien determinasi $\left(\mathrm{R}^{2}\right)$ diperoleh sebesar $17,2 \%$ diketahui bahwa Nilai Perusahaan mampu ditingkatkan oleh variabel Profitabilitas, Likuiditas, dan Rasio Aktivitas sebesar 17,2\% sedangkan sisanya dijelaskan oleh variabel lain yang tidak ikut di observasi, antara lain Solvabilitas, Struktur Modal, Ukuran Perusahaan dan lainnya.

Dari hasil penelitian yang telah dilakukan, maka diajukan saran sebagai berikut:

1. Untuk variabel profitabilitas peneliti menyarankan kepada perusahaan mengoptimalkan kinerja dengan cara melakukan efisiensi pada beban-beban operasional perusahaan, mengoptimalkan laba bersih, serta mengurangi jumlah aktiva tetap yang tidak produktif.

2. Untuk variabel likuiditas peneliti menyarankan kepada perusahaan mengoptimalkan kualitas rasio likuiditas dan mempertahankan rasio likuiditas yang dimiliki perusahaan, dengan melihat aset lancar dan kewajiban lancar. Aset lancar seperti kas, piutang usaha serta kewajiban lancar seperti hutang jangka pendek yang berupa laba ditahan.

3. Untuk variabel rasio aktivitas peneliti menyarankan kepada perusahaan mengoptimalkan perputaran aktiva yang dapat menunjang kegiatan penjualan menjadi stabil. Meningkatnya penjualan dapat menaikkan pendapatan perusahaan yang berpengaruh terhadap harga saham sehingga nilai perusahaanakan meningkat.

4. Bagi perusahaan supaya dapat memperhatikan komposisi optimal dari tingkat kemampuan mendapatkan laba, ketersediaan dana untuk memenuhi kewajiban jangka pendek, dan tingkat perputaran aktiva agar dapat meningkatkan nilai perusahaan Pertambangan sub sektor batubara di Bursa Efek Indonesia periode 2016-2018, karena nilai perusahaan merupakan salah satu pertimbangan investor dalam mengambil keputusan untuk melakukan investasi.

5. Bagi kreditur dan investor dalam memilih perusahaan yang terdaftar di Bursa Efek Indonesia dan akan dijadikan obyek investasi, sebaiknya melihat faktor-faktor yang mempengaruhi dan hubungannya terhadap nilai perusahaan seperti dalam penelitian ini yaitu profitabilitas, likuiditas dan rasio aktivitas. Dengan menganalisa faktor-faktor tersebut investor akan lebih mudah melihat prospek perusahaan, sehingga tidak melakukan kesalahan dalam investasi.

6. Penelitian selanjutnya diharapkan dapat memperbaiki keterbatasan yang ada dalam penelitian ini dan memperbanyak jumlah sampel serta tahun pengamatan untuk mendapatkan hasil yang menyeluruh. Selain itu, peneliti selanjutnya juga diharapkan mengganti variabel lainnya yang berbeda dari penelitian ini supaya dapat memberikan hasil yang lebih baik karena hasil penelitian ini mempunyai nilai adjusted $R$ square yang relatif kecil.

\section{Daftar Pustaka}




\section{BuanaAkuntansi}

Novita dan Yofhi

Vol. 5 No. 2

ISSN 2528-1119

E-ISSN 2580-5452

Amanah, Raghilia, (2014). Pengaruh Rasio Likuiditas dan Rasio Profitabilitas Terhadap Harga Saham (Studi pada Perusahaan Indeks LQ45 Periode 2008-2012). Jurnal Administrasi Bisnis (JAB), 12(1), 1-10

Analisa, Yangs. (2011). Pengaruh Ukuran Perusahaan, Leverage, Profitabilitas Dan Kebijakan Dividen Terhadap Nilai Perusahaan. Semarang: Skripsi Universitas Diponegoro Semarang.

Andriani, Putri Rizki. (2019). Pengaruh Tingkat Likuiditas, Profitabilitas dan Leverage Terhadap Nilai Perusahaan Pada Sub sektor Makanan dan Minuman Yang Tercatat di BEI Periode 2010-2017. Journal of Entrepreneurship,Management, and Industry (JEMI), 2(1), 48-60.

Arief Sugiono. (2009). Panduan Praktis Dasar Analisa Laporan Keuangan. Jakarta: PT. Grasindo.

Astutik, Dwi. (2017). Pengaruh Aktivitas Rasio Keuangan Terhadap Nilai Perusahaan (Studi Pada Industri Manufaktur). Jurnal STIE SEMARANG. 9(1), 35-53.

Fahmi, Irham. (2011). Analisis Laporan Akuntansi. Bandung: Alfabeta.

Fahmi, Irham. (2012). Analisis Kinerja Keuangan. Bandung: Alfabeta.

Halim, Abdul dan Mamduh M. Hanafi. (2009). Analisis Laporan Keuanga. Edisi 4. Yogyakarta: UPP STIM YKPN.

Hanafi, M. M., \& Halim, A. (2016). Analisis Laporan Keuangan. Yogyakarta: UPP STIM YKPN.

Hastuti, S. (2010). Analisis Kualitatif dan Kuantitatif Formal Dehid pada Ikan Asin di Madura. Agrointek, 4(2), 1-6.

Husain, T. (2019). An Analysis of Modeling Audit Quality Measurement Based on Decision Support Systems (DSS). European Journal of Scientific Exploration, 2(6), 1-9.

Husain, T., Sarwani, Sunardi, N., \& Lisdawati. (2020). Firm's Value Prediction Based on Profitability Ratios and Dividend Policy. Finance \& Economics Review, 2(2), 13-26.

Kasmir, (2014). Analisis Laporan Keuangan. Edisi Pertama, Cetakan Ketujuh. Jakarta: PT. Rajagrafindo Persada.

Munawir. (2014). Analisis Laporan Keuangan.Yogyakarta. Liberty.

Kismono, Gugup. (2010). Bisnis Pengantar. Yogyakarta: BPFE Yogyakarta.

Permana, A.A. Ngr Bgs Aditya dan Henny Rahyuda. (2019). Pengaruh Profitabilitas, Solvabilitas, Likuiditas, dan Inflasi Terhadap Nilai Perusahaan. E-Jurnal Manajemen Unud, 8(3), 1577-1607.

Pratiwi, N. W., \& Damayanthi, I. G. (2017). Analisis Perataan Laba dan Faktor-faktor yang Mempengaruhinya. E-Jurnal Akuntansi Universitas Udayana, 20(1), 496-525.

Panglipurningrum, Y. S., \& Dwiyani, A. (2019). The Effect of Profitability, Asset Structure, and Sales Growth on Capital Structure in Indonesia Stock Exchange in 2014-2017 (In Manufacturing Companies, Industrial Sectors and Consumer Goods in the Pharmaceutical Sector). KELOLA: Journal of Business and Management, 6(1), 9-20.

Rinnaya, Ista Yansi, Rita Andini dan Abrar Oemar. (2016). Pengaruh Profitabilitas, Rasio Aktivitas, Keputusan Pendanaan, Keputusan Investasi Terhadap Nilai Perusahaan (Studi Empiris Pada Perusahaan Manufaktur Yang Terdaftar Di BEI Tahun 2010-2014). Journal Of Accounting, 2(2).

Sartono, R. A. (2014). Manajemen Keuangan Teori dan Aplikasi (Edisi 4). Yogyakarta: BPFE Yogyakarta.

Sudana, Made, I. (2011). Manajemen Keuangan Perusahaan. Jakarta: Erlangga. 


\section{BuanaAkuntansi}

Sugiyono. (2016). Metode Penelitian Kombinasi (Mixed Methods). (M. Sutopo, Ed.) Bandung: CV. Alfabeta.

Supranto, J., \& Limakrisna, N. (2019). Petunjuk Praktis Penelitian Ilmiah untuk Menyusun Skripsi, Tesis dan Disertasi (5 ed.). Bogor: Penerbit Mitra Wahana Media.

Syamsudin dan Betik Kusuma Wardani. (2018). Analisis Pengaruh Corporate Social Responsibility, Profitabilitas dan Likuiditas Terhadap Nilai Perusahaan (Studi Pada Perusahaan Sektor Pertambangan yang Terdaftar di Bursa Efek Indonesia Tahun 20122016). Prosiding: The National Conferences Management and Business (NCMAB).

Wiagustini, Ni luh Putu. (2010). Dasar-Dasar Manajemen Keuangan. Denpasar: Udayana University Press.

Yanti, Isyanto, P., \& Mohd Saudi, M. H. (2020). Analysis of Financial Performance with Using Economic Value Added. International Journal of Psychosocial Rehabilitation (7), 3362-3370. 